NBER WORKING PAPER SERIES

\title{
SCIENCE AND INDUSTRY: TRACING THE FLOW OF BASIC RESEARCH THROUGH MANUFACTURING AND TRADE
}

\author{
James D. Adams \\ J. Roger Clemmons \\ Working Paper 12459 \\ http://www.nber.org/papers/w12459
NATIONAL BUREAU OF ECONOMIC RESEARCH
1050 Massachusetts Avenue
Cambridge, MA 02138
August 2006

The Andrew W. Mellon Foundation has generously supported this research. We thank Nancy Bayers and Henry Small of the Institute for Scientific Information (ISI) for assistance with the ISI data that we use in this paper. We thank Scott Stern and participants at seminars at the National Bureau of Economic Research and Rensselaer Polytechnic Institute for comments and suggestions that have improved this paper. The views expressed herein are those of the author(s) and do not necessarily reflect the views of the National Bureau of Economic Research.

(C2006 by James D. Adams and J. Roger Clemmons. All rights reserved. Short sections of text, not to exceed two paragraphs, may be quoted without explicit permission provided that full credit, including $\odot$ notice, is given to the source. 
Science and Industry: Tracing the Flow of Basic Research Through Manufacturing and Trade James D. Adams and J. Roger Clemmons

NBER Working Paper No. 12459

August 2006

JEL No. D2, O3

\begin{abstract}
$\underline{\text { ABSTRACT }}$
This paper describes flows of basic research through the U.S. economy and explores their implications for scientific output at the industry and field level. The time period is the late 20th century. This paper differs from others in its use of measures of science rather than technology. Together its results provide a more complete picture of the structure of basic research flows than was previously available.

Basic research flows are high within petrochemicals and drugs and within a second cluster composed of software and communications. Flows of chemistry, physics, and engineering are common throughout industry; biology and medicine are almost confined to petrochemicals and drugs, and computer science is nearly as limited to software and communications. In general, basic research flows are more concentrated within scientific fields than within industries.

The paper also compares effects of different types of basic research on scientific output. The main finding is that the academic spillover effect significantly exceeds that of industrial spillovers or industry basic research. Finally, within field effects exceed between field effects, while the within- and between industry effects are equal. Therefore, scientific fields limit basic research flows more than industries.
\end{abstract}

James D. Adams

Department of Economics

Rensselaer Polytechnic Institute

3406 Russel Sage Laboratory

Troy, NY 12180-3590

and NBER

adamsj@rpi.edu

J. Roger Clemmons

Institute for Child Health Policy

College of Medicine

PO Box 100147

Gainesville, FL 32610-0147

jrc@ichp.ufl.edu 


\section{Introductory Remarks}

Using a new body of evidence, this paper describes flows of basic research through the U.S. economy and explores their implications for scientific output in industries and fields. Besides the description of basic research flows, the analysis specifies the role of industry and field barriers in limiting R\&D spillovers to industries and fields. To undertake the study we use data on scientific papers written in firms and universities as well as citations made and received by the papers. This article differs from others in its examination of flows of scientific knowledge, rather than flows of applied technology.

Findings are as follows. Basic research flows are most intense in a cluster of petrochemicals and drugs and in a second cluster composed of software and communications. Flows of chemistry, physics, and engineering are general throughout industry; biology and medicine are almost confined to drugs and petrochemicals, and computer science is nearly as limited to software and communications. In general, basic research flows are more concentrated within fields than within industries.

In addition we assess comparative effects of different basic research flows, primarily R\&D spillovers, on output of scientific papers in an industry and field. The measure of effect is the elasticity of scientific papers with respect to basic research flows. We find that the academic spillover elasticity exceeds the industrial spillover elasticity and the elasticity of the industry R\&D stock. For academic and industrial spillovers we find that the within field elasticity exceeds the between field elasticity. Finally, the within and between industry elasticities for the industrial spillover are roughly equal. These findings form the basis for our claim that field is more a barrier to knowledge flows than industry is. 
Both descriptively and in terms of the explanation of scientific output, we find that aggregate R\&D spillovers are a more comprehensive measure of knowledge flows than citation rates. This is because spillovers capture frequency of citation events as well as size of the cited R\&D stock. All this is despite much recent emphasis on citation rates as a measure of knowledge flows.

The prior literature mostly consists of studies of flows of applied research among industries and technologies. Terleckyj (1974) and Griliches (1979) emphasize the importance of interindustry flows for productivity growth. Using data on patents and R\&D performed in lines of business owned by large U.S. firms in 1974, Scherer (1982a) computes a matrix of interindustry technology flows. Using this he reassigns firms' patents from industries where $R \& D$ is performed to industries of use, in order to calculate flows of $R \& D$ dollars between industries. The results indicate that most R\&D is used outside the industry. Scherer (1982b) shows that R\&D “used” has a significant effect on labor productivity while R\&D "performed" does not. Using a different sample and method Griliches and Lichtenberg (1984) find similar results, though with a larger role for R\&D performed. Mueller and Culbertson (1986) find something similar, that extra-industry innovations drive productivity gains in food processing.

Interindustry flows of technology play a significant role in industrial organization, economic history, urban economics, and management. General Purpose Technologies or GPTs (Bresnahan and Trajtenberg, 1995) are a dramatic case of interindustry technology flows. GPTs are defined as having wide applicability to downstream sectors and as increasing the returns to both earlier and subsequent technologies. Rosenberg (1963) offers an example of an early GPT, the machine tools industry in the $19^{\text {th }}$ century U.S. economy. In a related study Rosenberg (1979) confirms the broad role of capital goods and materials suppliers as sources of technology flows to user industries in the past. 
Jacobs (1969) emphasizes the flow of ideas across industries within cities, as well as the guiding role of industry diversity in urban prosperity. Glaeser et al. (1992) and Henderson et al. (1995) find empirical support for this view, in that initially diversified cities exhibit faster growth of employment and wages. In management studies, Klevorick et al. (1995) find that half the industries in the Yale Survey on Industrial Research and Development report sizable in-flows of technology from other industries. Likewise Von Hippel (1988) finds that innovation often begins with customers and suppliers located in different industries from the manufacturer.

Other research explores limits to knowledge flows thrown up by industries, technologies, and sciences. Differences in scientific employment bound R\&D spillovers between industries in Adams (1990). Even within firms technology groups are barriers to idea flows in Adams and Jaffe (1996) and Adams (1999). Patent classes limit rates of patent citation in Jaffe and Trajtenberg (1999), and science fields limit rates of science citation in Adams, Clemmons, and Stephan (2004 and forthcoming). Industry and field barriers to knowledge flows also arise in this paper's study of basic research flows through the U.S. economy ${ }^{1}$.

The rest of the paper consists of four sections. Section 2 discusses measurement of mean citation rates to basic research and aggregate spillovers of basic research. In comparing the two statistics it argues for the spillover as the more comprehensive measure of the influence of ideas. Next the section discusses data that we have collected to measure citation rates and spillovers. The section concludes with descriptive tables that characterize and compare academic and industrial science. Section 3 presents graphs and descriptive tables of the citation rates and spillovers. The discussion considers flows of basic research to firms that derive from

\footnotetext{
${ }^{1}$ Geographic restrictions on idea flows lie beyond the limits of this paper. Keller (2002) reviews the literature of international R\&D spillovers and analyzes intra- and inter-industry aspects of the spillovers. Peri (2005) studies resistance to patent citation imposed by region, country, language, and distance. Adams (2002) discusses and provides estimates of localization of knowledge spillovers within countries.
} 
universities and from other firms. The section concludes with Herfindahl indexes of concentration of the spillovers. The explanation of scientific output at the industry and field levels is the topic of Section 4. Output is expressed as a function of industry research, academic spillovers, and industrial spillovers. Regression analysis is then undertaken using a panel of industries, science fields, and years. The equations estimate elasticities of scientific output with respect to industry research as well as the R\&D spillovers. A final table tests for equality of the elasticities. Section 5 concludes.

\section{Citation Rates and R\&D Spillovers}

\subsection{Concepts}

The analysis relies on papers and citations made by industrial researchers in firms and on R\&D stocks of cited firms and universities. Since we are interested in industry and field effects we assign citing papers to the primary industry of the employer. This is the industry of largest sales in Compustat, our source for industrial R\&D. We assign cited papers to the primary industry of employers when a firm is cited and to the academic sector if a university is cited. Papers are assigned to the scientific field of the journal where they appear. Since citations link citing and cited papers together, they are able to measure influence only among active researchers.

In this paper we report two citation-based statistics. First, we report mean citation rates averaged by industry, field, and year. In the underlying data individual citation rates are numbers of citations made by papers in a specific citing firm, field, and year, to papers in specific cited firms or universities, fields, and years, divided by the number of papers in the cited group. The mean citation rate is the simple average of the individual rates by industry, field, and year. By analogy with search theory, the mean rate is the average propensity to draw on 
knowledge stocks of cited institutions. As we have seen, citations require sufficient human capital and emphasis on science in firms for publication to occur. Besides this, scientifically driven citations assume sufficient relevance of cited research to make it worthwhile to learn about the research of others.

However, as a spillover measure, citation rates have several shortcomings. While they capture the propensity to cite, this is contingent on citations having occurred. Also, the citation rate fails to capture frequency so the same mean rate can apply once, twice, or a thousand times. And finally, the citation rate does not consider the scale of the cited knowledge stock.

The aggregate R\&D spillover gets around many of these shortcomings. This is the sum of citation rates by citing industry, field and year multiplied by stocks of R\&D in the cited group. Zero citation rates diminish the spillover and are implicitly taken into account through the frequency of citation events. The product of the citation rates times the cited R\&D stocks incorporates size of the cited knowledge stock. In this way the aggregate R\&D spillover answers several objections to the mean citation rate.

As a proxy for underlying knowledge, R\&D stocks have some advantages. For a start, they provide an historical record of research. This activity goes beyond patents or papers, since learning from past research effort could be important whether it is published or not. And besides R\&D stocks capture size of effort in anticipation of future impact and are likely to be correlated with that impact. R\&D gets around nominal shifts in the patent-R\&D ratio, a problem that afflicts citation stocks. The ratio could decline due to a shift towards more important inventions. If so $R \& D$ would remain profitable despite the fall in the patent-R\&D ratio (Lanjouw and Schankerman, 2004). Also, in science the basic research stock is a forecast by granting agencies of future impact of the research. While these arguments in favor of R\&D stocks are not perfect, 
they help to explain why R\&D might perform better in this role than patent counts (Scherer, 1982a). We turn now to definitions of the citation rate and the aggregate R\&D spillover.

The individual citation rates in this paper are defined by citing and cited institutions, fields, and years. Citing institutions are firms; cited institutions are firms or universities. Notice that classification into industries is immediate from the primary industries of firms.

The raw citation rate is $c_{f_{g} y_{g} f_{d} y_{d}}^{k l} / n_{f_{d} y_{d}}^{l}$. Superscript $k$ stands for the citing firm while $l$ stands for the cited university or firm. Subscripts $f_{g}$ and $y_{g}$ indicate citing field and year; $f_{d}$ and $y_{d}$ indicate cited field and year. The numerator $c_{f_{g} y_{g} f_{d} y_{d}}^{k l}$ counts citations made by firm $k$ papers in citing field and year $f_{g}$ and $y_{g}$ to university or firm $l$ papers in cited field and year $f_{d}$ and $y_{d}$. This is divided by $n_{f_{d} y_{d}}^{l}$, the total number of papers in firm or universityl in $f_{d}$ and $y_{d}$ that could in principle be cited.

The mean citation rate $\bar{\rho}$ is defined over sets of citing and cited institutions, fields, and years:

$$
\bar{\rho}=\frac{\left[\sum_{k} \sum_{f_{g}} \sum_{y_{g}} \sum_{l} \sum_{f_{d}} \sum_{y_{d}}\left(c_{f_{g} y_{g} f_{d} y_{d}}^{k l} / n_{f_{d} y_{d}}^{l}\right)\right]}{N} .
$$

The term $N$ is the number of raw citation rates. Examples of the set of institutions are firms in the same industry and firms not in the same industry. Examples of the set of fields are fields that are the same and fields that are not the same, and so on. Equation (1) is the average propensity to cite, given the definitions of citing and citing institutions, fields, and years.

The aggregate R\&D spillover from universities to firms is the sum,

$$
S_{A}=\sum_{k} \sum_{f_{g}} \sum_{y_{g}} \sum_{l} \sum_{f_{d}} \sum_{y_{d}}\left(c_{f_{g} y_{g} f_{d} y_{d}}^{k l} / n_{f_{d} y_{d}}^{l}\right) \mathrm{R}_{f_{d}, y_{d}-1}^{l}
$$


This is the sum of individual citation rates times academic R\&D stocks $R_{f_{d}, y_{d}-1}^{l}$ in cited university $l$ and field $f_{d}$ lagged one year $y_{d}-1$. The definition is again flexible; it covers observations where firms in a specific industry and field cite universities in a specific field, and so forth.

The source for university R\&D is the CASPAR database (National Science Foundation, various years). We use CASPAR to construct individual R\&D stocks by university, field, and year. In turn we use the stocks and citation rates to construct R\&D spillovers from universities to specific firms and fields. The university data have two advantages over Compustat, our source for firm R\&D. University $R \& D$ is available by field over a dependably long period of time. Second, and consistent with our interest in basic knowledge flows university research concerns science rather than general R\&D.

Compustat records total R\&D expense by a firm. It makes no distinction between basic research and applied research and development; and within basic research it makes no distinction among sciences. To obtain a rough estimate of the aggregate $R \& D$ spillover from industry under these constraints, we make two adjustments. Since we lack R\&D by cited field we use the citation rate from a citing firm and field to a cited firm averaged over cited fields. In addition we multiply the total stock of R\&D in the cited firm by the ratio of basic research expenditure to total R\&D in its primary industry, since our interest is in basic research. The basic-total research ratio is about 0.05 in the industries that we study. The aggregate $R \& D$ spillover from firms is therefore:

$$
S_{I}=\sum_{k} \sum_{f_{g}} \sum_{y_{g}} \sum_{l} \sum_{y_{d}}\left(\overline{c_{y_{g} y_{d}}^{k l} / n_{y_{d}}^{l}}\right) b_{j} \mathrm{R}_{y_{d}-1}^{l}
$$


The bar placed over the citation rate indicates the average over cited fields. Besides this $b_{j}$ is the basic research ratio in the primary industry $j$ of the cited firm, and $R_{y_{d}-1}^{l}$ is the total R\&D stock of the cited firm. For example, suppose that engineering papers in firm X, located in communications services, cite papers of firm $\mathrm{Y}$, located in software and business services.

Then $\overline{c_{f_{g} y_{g} y_{d}}^{X Y} / n_{y_{d}}^{Y}}$ is the average citation rate by engineering papers in $\mathrm{X}$ to papers in $\mathrm{Y}$ averaged across cited fields, $\overline{R_{j,-1}^{Y}}$ is the lagged stock of R\&D in Y, and $b_{j}$ is the ratio of basic research to total R\&D in software and business services. Equation (3) represents our best measure of the spillover from other firms, though the fact that we cannot individually measure basic research in cited fields inevitably introduces errors in the spillover.

Finally, the lagged basic research stock $R_{K, y_{d}-1}$ of industry $K$ is

$$
R_{K, y_{d}-1}=\sum_{l \in K} b_{K} \mathrm{R}_{K, y_{d}-1}^{l}
$$

We use (4) to represent basic research that is privately available to firms in an industry.

\subsection{Data Sources}

The data consist of 230 thousand papers written in the top 200 U.S. R\&D firms in 1998 as ranked by their R\&D, and 2.43 million papers of the top 110 U.S. universities. The papers were published during 1981-1999. The top 200 firms make about one million citations to papers of top 110 universities as well as 600 thousand citations to papers of top 200 firms, including themselves. We remove self citations from a firm to itself from the data.

The source for the papers and citations data is ISI, the Institute for Scientific Information, in Philadelphia, Pennsylvania. Papers appear in more than 7,000 journals. Each journal is assigned to one science field. The main alternative to this method is to assign papers according to authors' departmental affiliations. But this strategy fails because information on authors' 
departments is incomplete ${ }^{2}$. The database is described in Adams, Black, Clemmons, and Stephan (2005) and in Adams, Clemmons, and Stephan (2004, and forthcoming).

For the university R\&D stocks in the academic R\&D spillover (see (2)) we use research expenditures by university, field, and year from the CASPAR database (National Science Foundation, various years). We express expenditures in millions of dollars, deflate using the implicit GDP deflator (1992=1.0), and accumulate the research stocks over the previous eight years using a depreciation rate of 0.15 . For the firm $R \& D$ stocks in the industrial $R \& D$ spillover (see (3)) we use total R\&D expense in Compustat (McGraw-Hill, various years). We express R\&D expense in millions of 1992 dollars and calculate an R\&D stock over the previous eight years using a depreciation rate of 15 percent. We employ published data on the ratio of basic to total research by industry from 1985-1999 from National Science Foundation (Research and Development in Industry, various years) and multiply this times firms' R\&D stocks in each industry to calculate an indicator of the firm's stock of basic research as this enters the spillover (3). The industry stock of basic research (4) is this indicator summed over firms in the same industry.

To undertake the regression analysis of Section 4 we extract a three-dimensional panel from the data. The panel consists of 11 industry groups, up to six main sciences, and up to 12 years ranging from 1988-1999. The industry groups, which include the top $200 \mathrm{R} \& \mathrm{D}$ firms according to their primary industry in Compustat, are as follows: petrochemicals (petroleum refining, chemicals excluding drugs and biotechnology, rubber, and plastics); drugs and biotechnology; metals (primary and fabricated); machinery (except computers); computers; electrical equipment;

\footnotetext{
${ }^{2}$ To explore this alternative we assigned all papers of Harvard University to one of the science fields in our data using address information. About a third of the papers could not be assigned; this caused us to abandon the address assignment method.
} 
instruments; communications services; software and business services; miscellaneous (agriculture, food \& tobacco, furniture, paper, miscellaneous manufacturing, and retail and wholesale trade). Clearly the industry groups extend well beyond manufacturing.

We have seen that the firm's primary industry is its industry of largest sales. It is not the firm's only industry, since large corporations usually span multiple industries. In work using plants owned by chemical firms in the Longitudinal Establishment Database of the U.S. Bureau of the Census, it has been shown that the plants cut across a large number of industries (Adams and Jaffe, 1996; Adams, 1999). Since this is the norm rather than the exception for large firms, the fact that companies exceed the bounds of a single industry may explain why industry is a weak barrier to basic research flows in the empirical work below.

Sciences included in the panel are biology, chemistry, computer science, engineering, medicine, and physics. These six fields account for nearly all papers in industry. The time period is 1988-1999. Starting the panel in 1988 allows for a build-up of R\&D spillovers and R\&D stocks as described in equations (1)-(4). The regression panel includes the dependent variable — numbers of scientific papers written in an industry, field, and year; and independent variables consisting of industry, field, and year fixed effects, the university and industry spillovers, and industry R\&D stock.

Table I reports the distribution of industrial papers by field and compares this with the distribution of academic papers. Distributions for the 11 industry groups form the rows; distributions for the entire industrial and academic sectors appear as the bottom two rows. Columns report total papers in an industry and sector and percentages of the papers in the six science fields. For the top three sciences in an industry we highlight the data and issue ranks in parentheses. Drugs and biotechnology publishes the most scientific papers, but petrochemicals, 
electrical equipment, transportation equipment, telecommunications services, and software and business services also publish in large amounts. Science publication is notably scarce in metals, machinery, and in miscellaneous agriculture and manufacturing.

Within drugs and biotechnology, biology, medicine, and chemistry rank first, second, and third. But this ranking is not representative of industry. Among industries biology is a top three field only in drugs and biotechnology, and petrochemicals. Medicine is in the top three only in drugs and biotechnology and instruments. In contrast engineering ranks in the top three in every industry except drugs and biotechnology with physics and chemistry nearly as prevalent. This shows up in the second to last row, which reports the science distribution for all industries. Engineering and physics tie for first; biology ranks third; and chemistry ranks fourth. The academic distribution differs considerably from this: biology and medicine account for 68 percent of papers. This simply reflects differences in the comparative shares of the scientific workforce in the two sectors. Engineers, physicists, and chemists dominate industrial papers while life scientists dominate academic papers. However, this difference is surely an understatement, because many industrial researchers, and especially engineers, do not publish or cite $^{3}$.

Industry and field could both restrict basic research flows. To this end, Table II examines differences in citation rates and R\&D spillovers within and between fields and industries. Within field, between field, and total dimensions are reported in columns. Rows contain citation statistics arranged by industry. Across columns, citation rates are higher within fields than between them. In addition 72 percent of the academic spillover and 60 percent of the industrial

\footnotetext{
${ }^{3}$ See Stephan, Sumell, Black, and Adams (2004), Table 2 for a description of the placement of PhD students to firms during the years 1997-1999. Forty-nine percent were in engineering, 11 percent were in chemistry, seven percent were in computer science, and six percent were in physics: thus 73 percent overall were in natural science. Only 10 percent were in biology and medicine.
} 
spillover occur within fields. Citation rates to other firms are higher than to universities, possibly because industrial papers are more similar and more relevant than academic papers. Citation occurs at almost the same rate between industries than within them, but R\&D spillovers between industries account for 64 percent of the total. These differences in sources of spillovers suggest that field may obstruct flows of basic research to a larger extent than industry. It is noteworthy as well, that academic spillovers are twice as large as industrial spillovers. This gap would be even larger if the citation rate to industrial science were not the higher of the two.

\section{Descriptive Findings}

\subsection{Interactions with Universities}

This section describes the industry and field structure of the citation statistics. To visualize this structure we rely on three-dimensional column graphs. In graphs of this kind, discontinuous dimensions (industry and field) map into a continuous variable (citation statistics). For convenience we abridge the 11 industries in Table I to six. We do so by forming three aggregates: metals, machinery, and miscellaneous agriculture and manufacturing; computers, communications, and software; and electrical equipment and instruments. The results for firmuniversity interactions are shown in Figures I and II.

Figure I shows high rates of citation to computer science, intermediate rates to chemistry, engineering, and physics; and low citation rates to biology and medicine. But as we have seen, citation rates do not capture frequency or the size of cited R\&D. Figure II, which we rotate slightly in a clockwise direction, shows how important this distinction is. It shows that the structure of academic spillovers is completely different from the structure of citation rates in Figure I. The citation rate to computer science is high, but its spillover is low because of a low frequency of citation rate events and a small R\&D stock. Figure II shows that R\&D spillovers of 
biology and medicine are huge in drugs and biotechnology despite the fact that citation rates to biology and medicine are low. There is thus only a weak correlation between citation rates and spillovers. Finally note the cluster of secondary peaks of academic spillovers from computer science, engineering, and physics, to computers, etc. and electrical equipment, etc.

Table III takes a close look at the university-industry spillover structure. It shows the top four academic spillovers by industry and by citing and cited field. Besides the spike of biological and medical spillovers as well as their near-confinement to drugs, etc., the table uncovers spikes in petrochemicals, electrical equipment, transportation equipment, communications services, and software and business services. Table III indicates that 39 of the 44 top spillovers occur in the same field, showing in a different way the importance of field as a limiting factor in basic research flows.

\subsection{Interactions with Other Firms}

We undertook a similar exercise for citation rates and spillovers from other firms. Figure III, which is again rotated slightly, shows citation rates by citing industry and cited industrial field. Compared with Figure I overall rates are higher and more nearly equal across fields and industries. Figure IV presents aggregate R\&D spillovers from other firms. Not surprisingly, compared to Figure II, industrial spillovers are less dominated by biology and medicine. Another aspect of Figure IV is the significant cluster of industrial spillovers in computers, etc. and in electrical equipment, etc.

Figures V and VI study interactions among industries. Figure V presents interindustry citation rates. Citation rates to science-intensive industries—petrochemicals, drugs, etc., computers, etc., and electrical equipment, etc.-are low compared with citation rates to metals, 
machinery, and miscellaneous, a group that does little in the way science ${ }^{4}$. But Figure VI shows that spillovers from metals, etc. are quite small compared with other industries. This again reflects on the deficiencies of the citation rate as a spillover indicator. In Figure VI spillovers from drugs, etc., show up almost entirely in petrochemicals and drugs. In contrast spillovers from petrochemicals are flat but widely dispersed. This is also true of spillovers from computers etc.

Like Table III, Table IV shows the top six industrial R\&D spillovers by citing and cited industry and field. As one would expect this list is dominated by chemistry, physics, and engineering, with biology and medicine present mostly in petrochemicals and drugs. Withinfield spillovers account for 54 of the top 72 spillovers. This is a smaller proportion than in Table III and suggests that industrial science is more applied, eclectic, and interdisciplinary than academic science.

\subsection{Concentration of $R \& D$ Spillovers}

While the figures and tables are helpful in visualizing particular spikes and clusters in aggregate $R \& D$ spillovers it would helpful to quantify concentration of R\&D spillovers to industries. To this end we calculate Herfindahl indexes of concentration based on shares of R\&D spillovers to each industry. To begin with, we compute a field cited index for recipient industry $K$ :

$$
H_{K}^{F}=\sum_{f \in F_{d}^{K}} s_{f K}^{2},
$$

\footnotetext{
${ }^{4}$ Smaller bodies of knowledge could readily exhibit higher citation rates. To see why assume that citations to different sciences yield a marginal benefit that diminishes at a similar rate with respect to search over articles and assume that the constant marginal cost of making a citation is similar across sciences. Given these assumptions the equilibrium citation rate to smaller literatures will be higher than to larger ones. Of course, if the marginal cost is higher for more technical papers then it would follow that small but highly technical literatures would exhibit lower citation rates.
} 
We calculate (5) for both academic and industrial spillovers. Here $F_{d}^{K}$ stands for the set of fields that $K$ cites and $s_{f K}$ is the share of field $f$ in spillovers to $K$. Since there are six fields the lower bound on (5) occurs when all shares equal $1 / 6 \approx 0.17$. Squaring and summing the shares, (5) also equals 0.17 .

In the case of industrial spillovers we define an industries cited index for citing industry $K$ :

$$
H_{K}^{I}=\sum_{j \in I_{d}^{K}} S_{j K}^{2}
$$

Here $I_{d}^{K}$ is the set of industries that $K$ cites; $s_{i K}$ is the share of industry $i$ in spillovers to $K$. The lower bound occurs when all shares equal $1 / 11 \approx 0.09$. Squaring and summing the shares, (6) also equals 0.09 .

Table V displays the results. Rows indicate citing industry; columns indicate the Herfindahl indexes. The first two columns use the field-cited index $H_{K}^{F}$ as defined in (5). Drugs, etc. and machinery, etc. are the two most concentrated industries. In drugs most spillovers derive from biology and medicine. In machinery most spillovers derive from chemistry and physics. The third column reports the Herfindahl index $H_{K}^{I}(6)$ of spillovers among cited industries. The two most concentrated industries are drugs, etc., and communications services. Firms in these industries receive most of their spillovers from the same or a nearby industry. This is partly because of their fields of specialization: biology and medicine are concentrated in drugs and petrochemicals, and computer science, engineering, and physics are concentrated in communications services and electrical equipment.

\section{Explaining Scientific Output in Industries and Fields}

Section 3 has described citation statistics and it has mapped points of origin and destination of basic research flows within the U.S. economy. The rest of the empirical work tries to explain 
the output of scientific papers using the stock of basic research in an industry, academic and industrial spillovers, and fixed effects. We estimate the following knowledge production function, expressed in logarithms:

$$
\begin{gathered}
\ln \left(\text { papers }_{i j t}\right)=\alpha_{0}+\alpha_{t}^{\prime} D_{t}+\alpha_{I}^{\prime} D_{I}+\alpha^{\prime} D_{F}+\beta_{R} \ln \left(R_{i t}\right)+\beta_{A} \ln \left(S_{A, i j t}\right)+ \\
\beta_{\text {ZA }}\left[Z_{A} \times \ln \left(S_{A, i j t}\right)\right]+\beta_{I} \ln \left(S_{I, i j t}\right)+\beta_{Z I}\left[Z_{I} \times \ln \left(S_{I, i j t}\right)\right]+u_{i j t}
\end{gathered}
$$

Terms entering (7) are

papers $_{i j t}$ —number of scientific papers (or citation-weighted papers) written in industry $i$ and field $j$ at time $t$

$D_{t}, D_{I}, D_{F}$ - vectors of year, industry, and field fixed effects

$R_{i, t-1}$ - stock of basic research in industry $i$ at time $t-1$

$S_{\text {Aijt }}, S_{\text {Iijt }}$ - spillovers of basic research from academia and industry (plus 0.001)

to industry $i$ and field $j$ at time $t$

$Z_{A}$ —dummy indicator equal to 1 when $S_{\text {Aijt }}>0$ and 0 otherwise

$Z_{I}$-dummy indicator equal to 1 when $S_{\text {Iijt }}>0$ and 0 otherwise

$u_{i j t}$ —normally distributed error term

Since we fit the logarithm of papers on the logarithms of the $\mathrm{R} \& \mathrm{D}$ indicators, the $\beta$ coefficients are elasticities. Also, we add 0.001 to each spillover in order to take logarithms when it is zero. For this reason we introduce interaction terms involving $Z_{A}$ and $Z_{I}$ times the logarithms of the spillovers. As we shall see the interaction terms handle cases where the spillover is zero.

We estimate (7) on the panel data set discussed in Section 2. This is arranged according to industry, field, and year to address the industry and field relationships of interest. After missing values are excluded the data include 747 observations. We vary (7) by dropping fixed effects, by 
dropping interaction terms, by varying the sample, and by switching between papers and citation-weighted papers. Table VI contains basic specifications. Throughout, the regressions report robust standard errors ${ }^{5}$. Notice as well that we tag key variables with their $\beta$ coefficients for tests of equality restrictions among coefficients later on.

Equations VI.1 to VI.3 omit fixed effects. VI.1 fits a simple regression of the logarithm of scientific papers on the logarithm of the industry's basic research stock. This elasticity is positive and highly significant. VI.2 adds logarithms of the academic and industrial research spillovers to VI.1. This increases $\mathrm{R}^{2}$ from 0.35 to 0.87 but causes a sharp drop in the elasticity of industry basic research. The industry stock is however, a crude proxy for past basic research, and this may result in a downward bias when spillovers are included. The spillover elasticities are positive and highly significant; the academic spillover has more than three times the effect of the industrial spillover. To capture zero spillovers VI.3 adds the zero interaction terms that we have discussed. As expected, coefficients of the interaction terms are negative and roughly cancel the main spillover coefficients. Or to see this in a different light, the spillover has no effect when it is zero, since in that event both the main and interaction terms differ from zero.

VI.4 and VI.5 add fixed effects to VI.2 and VI.3, and these are now within group regressions. The R\&D coefficients remain significant and do not change systematically. The elasticity of industry basic research increases, but the industrial spillover elasticity decreases.

The rest of the table consists of variations on VI.5. VI.6 drops drugs, etc. The reason is this. The figures and descriptive tables show that spillovers in drugs and biotechnology exceed other spillovers, so this industry could have an undue influence on the results. But in fact the

\footnotetext{
${ }^{5}$ The heteroskedasticity-robust variance-covariance matrix is $\tilde{V}=\left(X^{\prime} X\right)^{-1}\left(\sum_{i=1}^{N} \hat{u}_{i}^{2} x_{i}^{\prime} x_{i}\right)\left(X^{\prime} X\right)^{-1}$. The expectation of this matrix reduces to $V=\sigma^{2}\left(X^{\prime} X\right)^{-1}$ under the hypothesis of homoskedasticity.
} 
exclusion has little effect and the elasticities stay about the same. VI.7 drops metals, machinery, and miscellaneous from the sample. Since these three industries produce little science, they are also outliers. Apart from a slight decline in the industry basic research elasticity and a rise in the elasticity of academic spillovers, the results stay about the same. In VI.8 and VI.9 the dependent variable consists of citation-weighted papers. Since these are five-year "forward" citations in an industry and field, the data are missing in 1996-1999 and this causes a large drop in sample size. Equation VI.8 repeats VI.3 using citation-weighted papers, omitting fixed effects. R\&D elasticities are higher in VI.8, suggesting that the effect of R\&D is partly to produce higher impact research. Equation VI.9 repeats VI.5 including fixed effects. The elasticity of the industry research stock turns negative: evidently its effect cannot be identified separately from industry, field, and year. The spillover elasticities remain positive and significant.

Table VII introduces decompositions of the academic and industrial spillovers. We begin with a few preliminaries. Since the table separates spillovers into within and between components, we introduce zero interaction terms for each one. As before elasticities of the interaction terms are negative and cancel main spillover elasticities. Thus spillover components have no effect when they are equal to zero. Also, the different spillover decompositions have little effect on the elasticity of industry research, which stays around 0.20 . Notice that we tag key variables with corresponding $\gamma$ coefficients for later tests of equality restrictions. All the equations use VI.5 as the baseline specification.

Henceforth we focus on the R\&D spillovers. VII.1 decomposes these into within and between field components. Not surprisingly main elasticities are positive, interaction elasticities are negative, and both are usually significant. The within field component consists of spillovers where citing and cited fields are the same. The between field component consists of spillovers 
where citing and cited fields differ. If within field research is more relevant, its elasticity would be the larger of the two. This is what VII.1 finds: the within field academic elasticity is 0.38 , about twice the between field elasticity (0.18). The within field industrial elasticity is 0.15 and is about 40 percent larger than the between field elasticity (0.11).

In VII.2 we maintain the within- and between- field distinction for academic spillovers, but we separate the industrial spillover into within- and between- industry components. As before, the within industry component consists of spillovers where citing and cited industries are the same and the between industry component consists of spillovers where this is not true. If basic research within the same industry is more relevant, then the within elasticity should exceed the between elasticity. However, VII.2 rejects this hypothesis. It finds that the between industry elasticity is 0.15 , larger than the within elasticity (0.12).

VII.3 considers a four component breakdown of the industrial spillover. In this equation we consider both within- and between- field and industry dimensions. Making due allowance for collinearity, VII.3 tells a similar story to VII.1 and VII.2. The within field, within industry elasticity is 0.10 and the within field, between industry elasticity is 0.09 . The two are almost the same, suggesting that industry has little effect on flows of basic research. The between field, within industry elasticity is 0.01 and the between field, between industry elasticity is 0.09 , on average falling short of the within field estimates. VII.3 confirms the importance of the within field component as an impediment to the impact of basic research on scientific output, and it denies any corresponding role for industry.

Table VIII tests for equality of the elasticities of the R\&D indicators in selected regressions from Tables VI and VII. Using regressions VI.3 and VI.5 the table tests for equality of the elasticities of the industry basic research stock and the two spillovers. Where $\beta_{R}$ is the elasticity 
of the industry basic research stock and $\beta_{A}$ is the elasticity of the academic basic research spillover, Test 1 decisively rejects the hypothesis of equality, finding that the academic elasticity is significantly larger than that of industry basic research. Likewise Test 2 checks for and rejects, equality of $\beta_{A}$ and $\beta_{I}$. Therefore, the academic spillover elasticity significantly exceeds the industry elasticity.

Tests 3 to 11 apply to Table VII. Test 3 tests for and rejects equality of the elasticities of the academic, within and between field spillovers in regressions VII.1-VII.3. Test 4 tests for and rejects equality of the within field, academic and industrial spillover elasticities. Test 5 accepts equality of the between field, academic and industrial spillover elasticities. Therefore, the academic spillover elasticity is significantly greater than the industrial spillover within fields, but not between fields. This strongly suggests that the stronger influence of universities occurs within fields, and equally strongly it reflects the more eclectic nature of industry research. Consistent with this hypothesis, test 6 accepts equality of within and between field industrial spillover elasticities. Test 7 applies to VII.2 and accepts equality of within and between industry elasticities of the industrial spillover. This confirms, more formally, that spillovers from the same industry do not differ in their effect from spillovers outside the industry. Remaining tests apply to VII.3. Test 8 rejects equality of the within and between field, within industry elasticities, implying that the within field elasticity is larger. Test 9 accepts equality of elasticities within and between fields and between industries. Tests 10 and 11 accept equality of the elasticities within and between industries. 
The tests yield five statements about the effect of basic research flows on the production of industrial science. Following (7), recall that the effects are elasticities ${ }^{6}$. The five statements are: (1), the academic spillover has a larger effect than either industry basic research or the industrial spillover; (2), within fields, the academic spillover effect exceeds the industrial spillover effect; (3), within fields, effects tend to be larger than between fields, so that field is a resistance factor in the production function for science; (4), within industries, effects are the same as between industries, so that industry is not a resistance factor; and (5), the within field effect of the industrial spillover occurs within the industry.

Besides (7) we carried out nonlinear least squares (NLLS) regressions in the style of Griliches (1986), which allows for arithmetic comparisons of an extra million dollars of different spillover components rather than one percent changes as in (7). We illustrate this approach by reporting estimates of a knowledge production function that, like VII.1, includes within and between field effects:

$$
\begin{aligned}
\ln \left(\text { papers }_{i j t}\right)= & 0.155 * \ln \left(R_{i j t}\right)+0.549 * \ln \left[\left(S_{A, W F, i j t}+0.001\right)+\right. \\
& (0.024) \quad(0.043) \\
& \left.0.626 * S_{A, B F, i j t}\right]-0.542 * Z_{A} * \ln \left(S_{A, i j t}+0.001\right)+ \\
& (0.189) \quad(0.076) \\
& 0.246 * \ln \left[\left(S_{I, W F, i j t}+0.001\right)+0.720 * S_{I, B F, i j t}\right]- \\
& (0.032) \\
& 0.265 * Z_{A} * \ln \left(S_{A, i j t}+0.001\right) \\
& (0.034) \\
\mathrm{N}=747, \mathrm{R}^{2}= & 0.992, \text { Root MSE }=0.394
\end{aligned}
$$

The equation includes fixed effects for year, industry, and field. Its nonlinearity is clear from the coefficients for the between field components of the spillovers, which lie inside the logarithms. The coefficients are less than 1.0. This difference is marginally significant for academic

\footnotetext{
${ }^{6}$ Since the elasticities are percentage changes per one percent change in each right-hand side variable, we are using one percent changes in these comparisons.
} 
spillovers. The estimates suggest that an extra million dollars of between-field academic and industrial spillovers is 60-70 percent of their within-field counterparts.

\section{Concluding Discussion}

This paper provides new evidence on the transmission of basic research through the U.S. economy. As indicators of basic research flows this paper distinguishes strongly between citation rates and aggregate $\mathrm{R} \& \mathrm{D}$ spillovers. Though the citation rate gets at the propensity to draw from a particular body of knowledge, it does so contingent on the existence of citation. Furthermore, it takes no account of the frequency of citation events, nor does it consider the size of cited knowledge stocks. To illustrate, the citation rate to academic computer science is exceptionally high. But the frequency of citation events to computer science is low, as is its R\&D stock. This principle becomes clear from repeated study of the descriptive figures and tables. Besides this, the descriptive materials indicate points of origin and destination for the academic and industrial spillovers.

Likewise we investigate the role of industry basic research and R\&D spillovers in the production of scientific knowledge as evidenced by papers. While it is not easy at all times to disentangle the industry stock from fixed effects, in general we find that the industry stock as well the academic and industrial spillover contribute to scientific output. Of the three R\&D inputs academic spillovers have the largest effect, measured by the elasticity of papers with respect to the input. However, there is reason to think that errors in the industry basic research stock lead to downward biases in its effect.

Besides the study of total spillovers we decompose the spillovers into within and between field components for academic and industrial spillovers, and into within and between industry components for industrial spillovers. In brief, we find that within field effects on scientific 
output exceed between field effects, but that within and between industry effects are statistically indistinguishable. Thus field seems to be a barrier to flows of basic research in a way that industry is not.

Throughout this paper has relied on scientific papers and citations to these papers to gauge science's influence in industry. This is a reasonable strategy for assessing the influence of science on research output, which is the use to which we put it in this paper. But the broader question perhaps is that of the role of flows of human capital as well as scientific research in the productivity of final goods and services. That question must await the development of comprehensive data on stocks and flows of scientists and engineers and their human capital attributes. 


\section{References}

Adams, James D., “Fundamental Stocks of Knowledge and Productivity Growth,” Journal of Political Economy 98 (August 1990): 673-702.

, “The Structure of Firm R\&D, the Factor Intensity of Production, and Skill

Bias,” Review of Economics and Statistics 81 (August 1999): 499-510.

, “Comparative Localization of Academic and Industrial Spillovers,” Journal

of Economic Geography 2 (July 2002): 253-278.

, and Adam B. Jaffe, “Bounding the Effects of R\&D: An Investigation Using

Matched Establishment-Firm Data,” RAND Journal of Economics 27 (Winter 1996):

700-721.

, Grant Black, J. Roger Clemmons, and Paula E. Stephan, “Scientific Teams

and Institutional Collaborations: Evidence from U.S. Universities, 1981-1999,” Research

Policy 34 (April 2005): 259-285.

, J. Roger Clemmons, and Paula E. Stephan, “Standing on Academic Shoulders:

Measuring Scientific Influence in Universities,” Cambridge, Massachusetts: NBER

Working Paper No. 10875, October 2004, Forthcoming in Les Annales d'Economie et

de Statistique.

Bresnahan, Timothy F., and Manuel Trajtenberg, “General Purpose Technologies: 'Engines of Growth?',’ Journal of Econometrics 65 (1995): 83-108.

Glaeser, Edward L., Hedi D. Kallal, Jose A. Scheinkman, and Andrei Shleifer, “Growth in Cities,” Journal of Political Economy 100 (December 1992): 1126-1151.

Griliches, Zvi, “Issues in Addressing the Contribution of R\&D to Productivity Growth,” Bell 
Journal of Economics 10 (Spring 1979): 92-116.

, "Productivity, R\&D, and Basic Research at the Firm Level in the 1970s,"

American Economic Review 76 (March 1986): 141-154. , and Frank Lichtenberg, "Interindustry Technology Flows and Productivity

Growth: A Reexamination,” Review of Economics and Statistics 66 (May 1984): 324329.

Henderson, Vernon, Ari Kuncoro, and Matt Turner, “Industrial Development in Cities,” Journal of Political Economy 103 (October 1995): 1067-1090.

Jacobs, Jane, The Economy of Cities, New York: Vintage Books, 1969.

Jaffe, Adam B., and Manuel Trajtenberg, "International Knowledge Flows: Evidence from Patent Citations,” Economics of Innovation and New Technology 8 (1999): 105-136.

Keller, Wolfgang, “Trade and the Transmission of Technology,” Journal of Economic Growth 7 (March 2002): 5-24.

Klevorick, Alvin K., Richard C. Levin, Richard R. Nelson, and Sidney G. Winter, “On the Sources and Significance of Interindustry Differences in Technological Opportunities,” Research Policy 24 (1995): 185-205.

Lanjouw, Jean O., and Mark Schankerman, "Patent Quality and Research Productivity: Measuring Innovation with Multiple Indicators,” The Economic Journal 114 (April 2004): 441-465.

Mueller, Willard F., and John D. Culbertson, "Inter-industry Technology Flows in the U.S. Food-Processing Industries,” Managerial and Decision Economics 7 (September 1986): 163-168.

National Science Foundation, CASPAR Database, Arlington, Virginia: www.nsf.gov/statistics 
, Research and Development in Industry, Arlington, Virginia:

various years.

Peri, Giovanni, “Determinants of Knowledge Flows and Their Effect on Innovation,” Review of

Economics and Statistics 87 (May 2005): 308-322.

Rosenberg, Nathan, “Technological Change in the Machine Tool Industry, 1840-1910,” Journal

of Economic History 23 (December 1963): 414-443; reprinted as Chapter 1 of

Perspectives on Technology, New York, Cambridge University Press, 1976.

, "Technological Interdependence in the American Economy,” Technology

and Culture 21 (January 1979): 25-50; also Chapter 2 of Inside the Black Box:

Technology and Economics, Cambridge, UK: Cambridge University Press, 1982.

Scherer, F. Michael, “Interindustry Technology Flows in the United States,” Research Policy 11 (August 1982a): 227-245.

, “Interindustry Technology Flows and Productivity Growth,” Review of

Economics and Statistics 64 (November 1982b): 627-634.

Stephan, Paula E., Albert J. Sumell, Grant C. Black, and James D. Adams, "Doctoral Education and Economic Development: The Flow of New PhDs to Industry,” Economic Development Quarterly 18 (May 2004): 151-167.

Standard and Poor's Compustat, New York: McGraw-Hill, various years.

Terleckyj, Nestor E., "Effects of R\&D on the Productivity of Industries,” (1974) Washington, DC: National Planning Association.

Von Hippel, Eric, The Sources of Innovation, New York: Oxford University Press, 1988. 


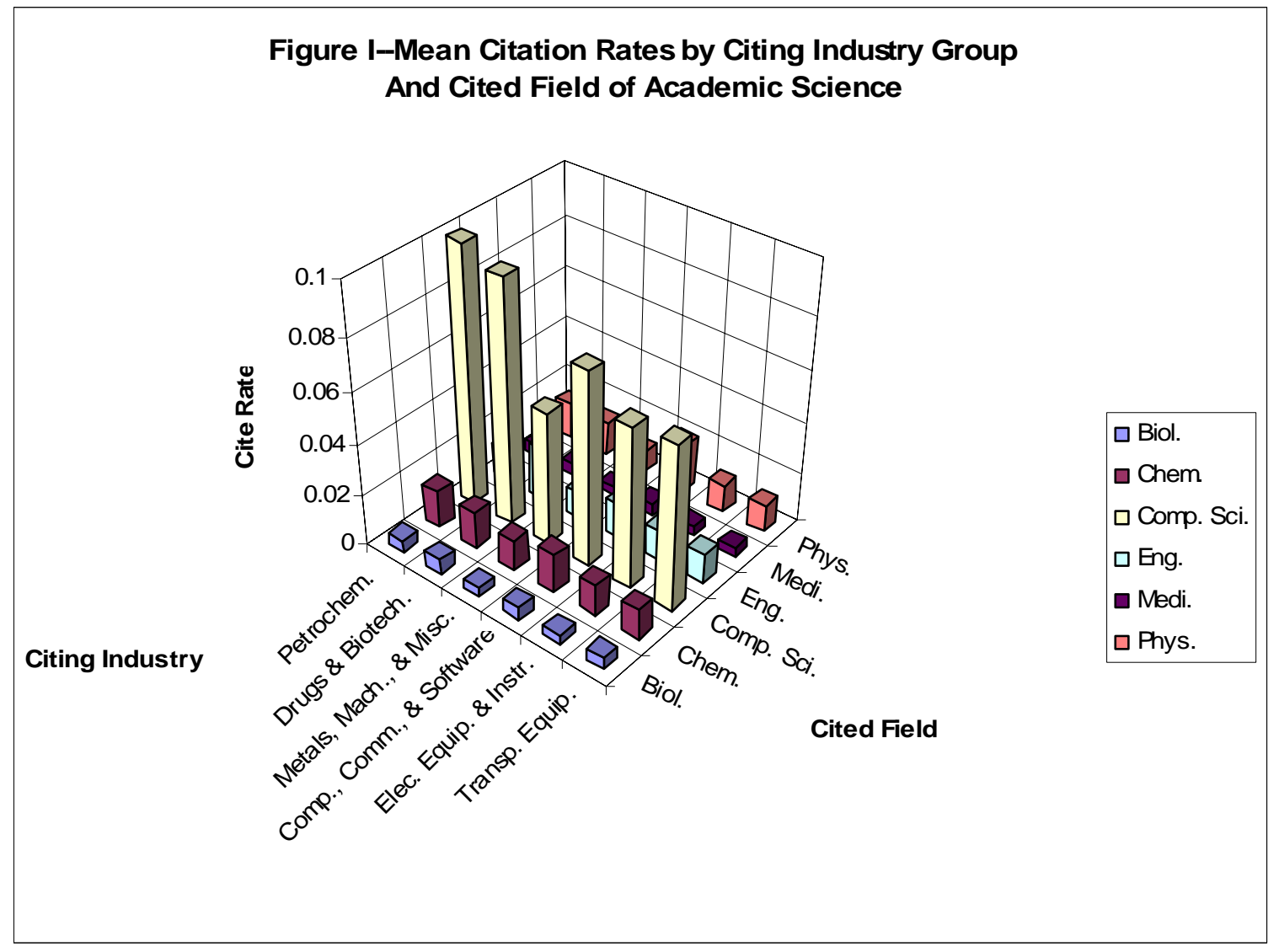

Figure II--Academic R\&D Spillover by Citing Industry Group And Cited Academic Field of Science

Citing Industry

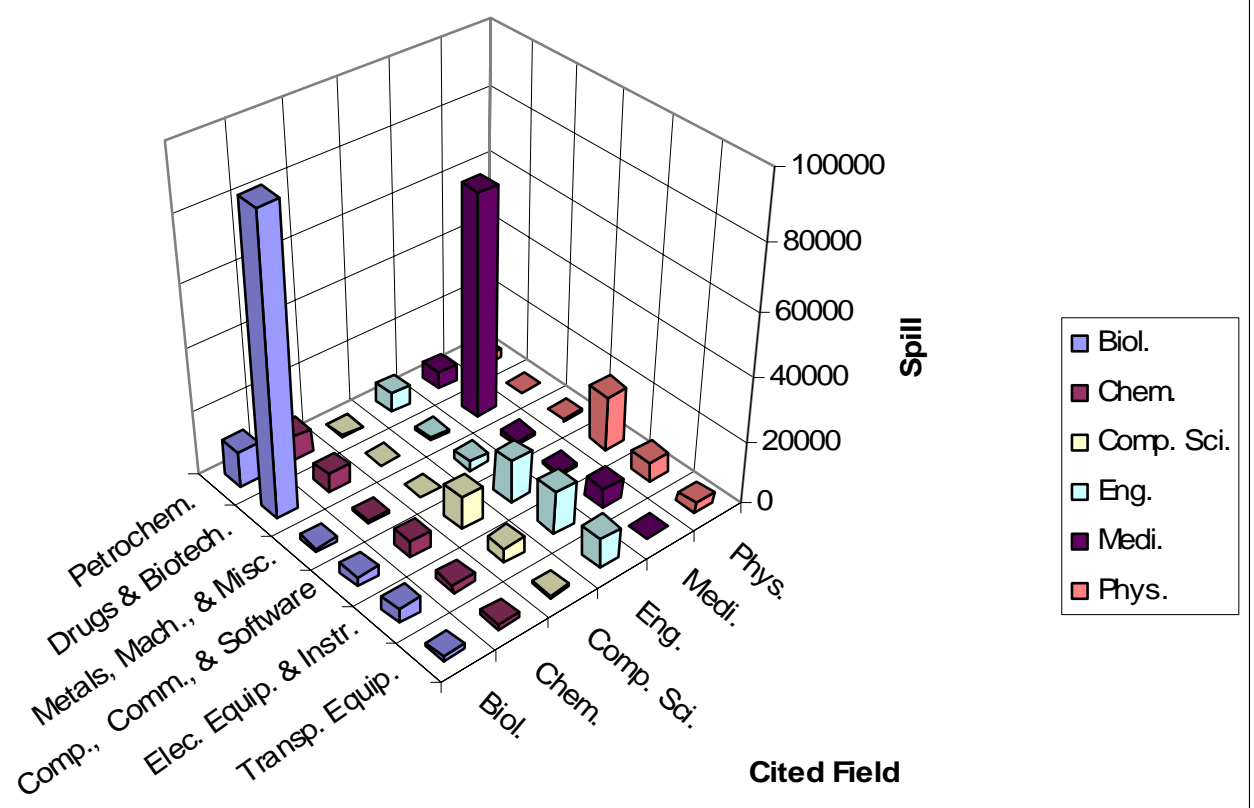



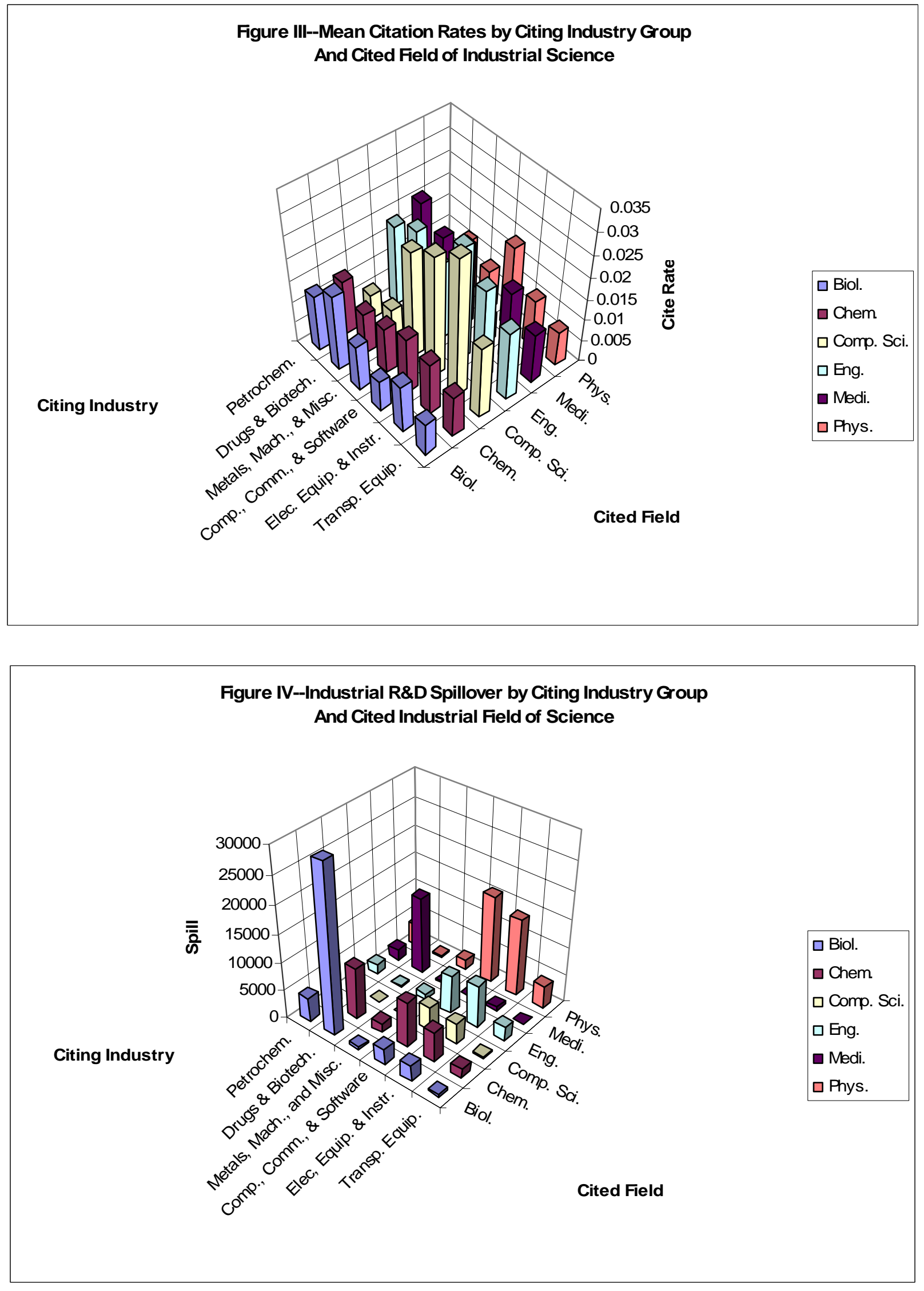


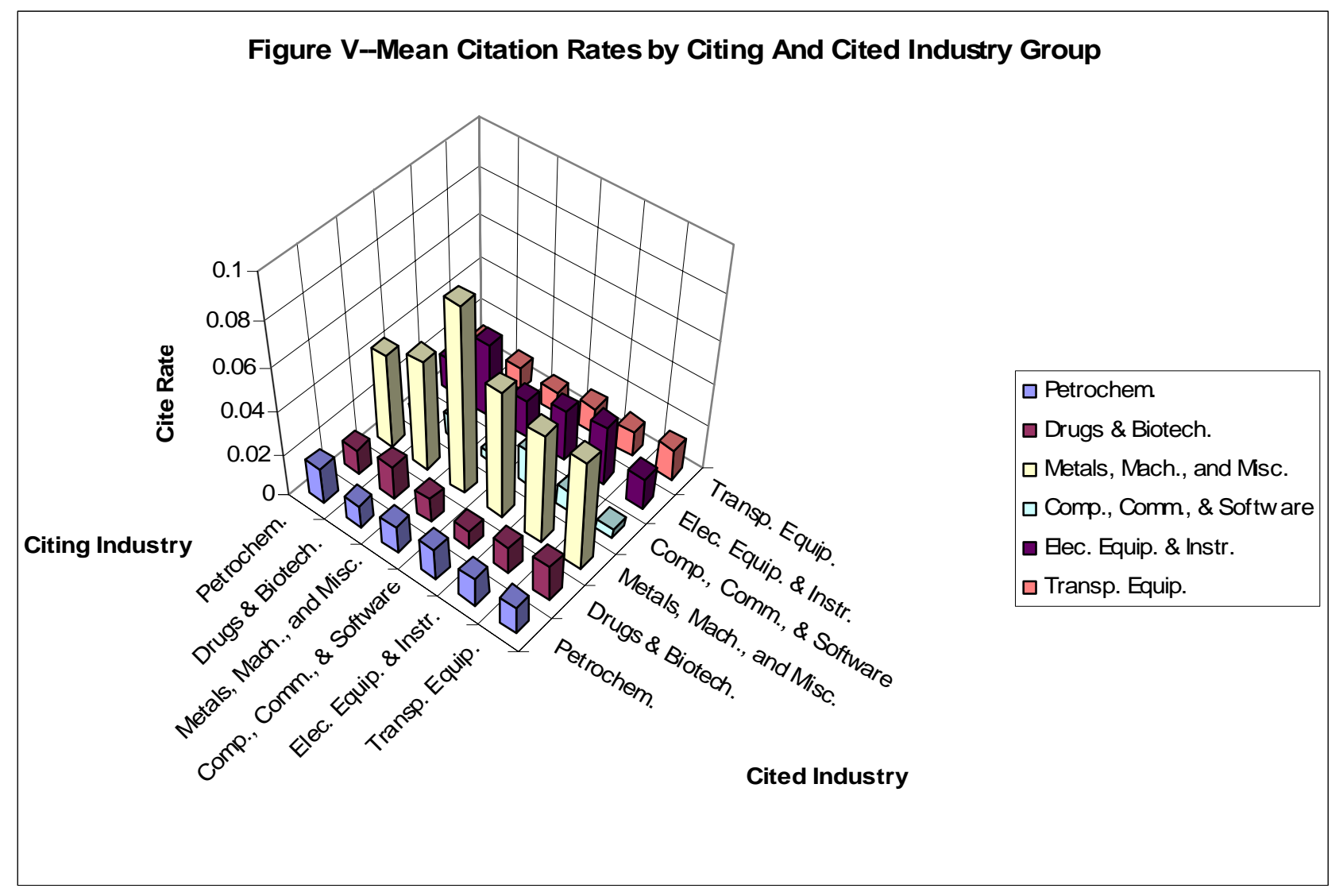

Figure VI--Industrial R\&D Spillovers by Citing and Cited Industry Group

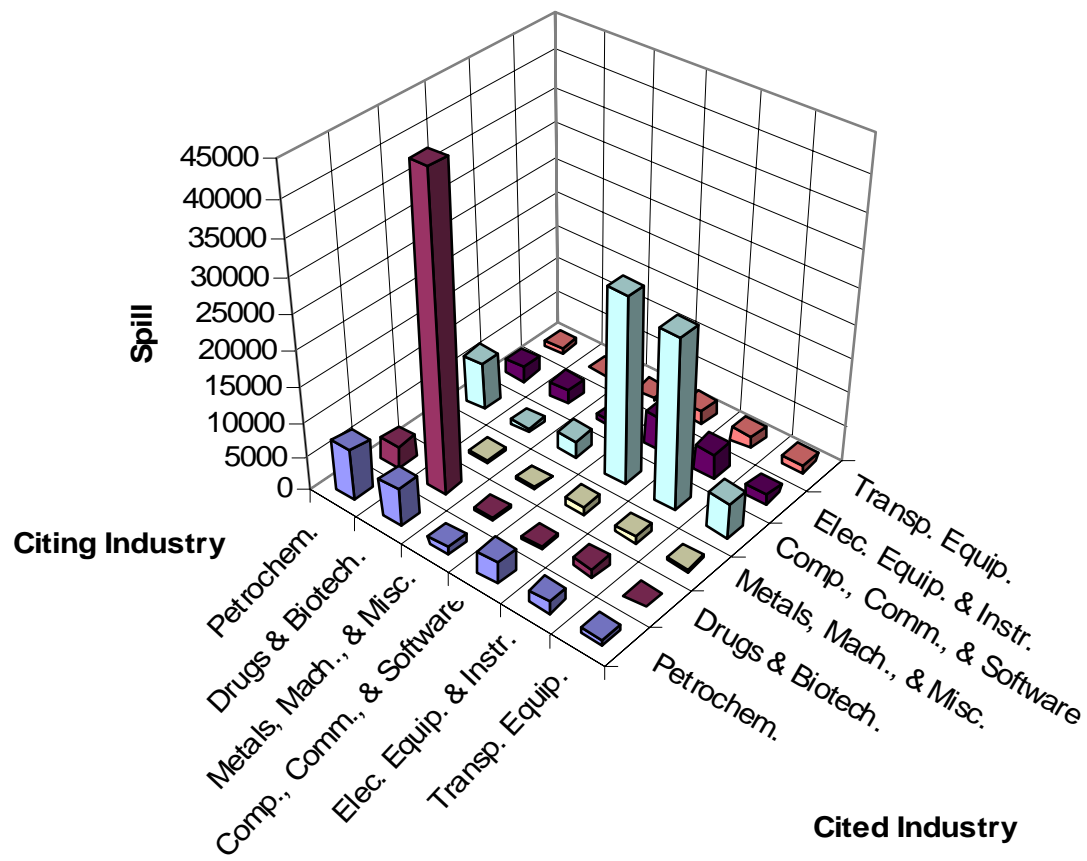

$\square$ Petrochem

$\square$ Drugs \& Biotech.

$\square$ Metals, Mach., \& Misc.

$\square$ Comp., Comm, \& Software

घec. Equip. \& Instr.

$\square$ Transp. Equip. 
Table I

Distribution of Industrial Scientific Papers

\begin{tabular}{|c|c|c|c|c|c|c|c|}
\hline \multirow[b]{2}{*}{ Industry or Sector } & \multirow[b]{2}{*}{ 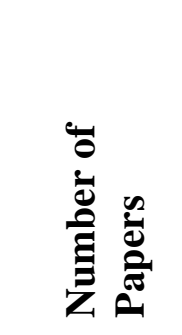 } & \multicolumn{6}{|c|}{ Percentage Distribution by Field } \\
\hline & & 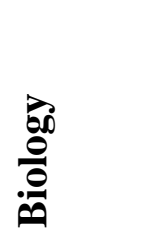 & 苞 & ڤ્ّ & 四 & & $\frac{n}{\sqrt[n]{n}}$ \\
\hline Petrochemicals & 30,679 & $\begin{array}{c}18.7 \% \\
(3)\end{array}$ & $\begin{array}{c}36.2 \% \\
\text { (1) }\end{array}$ & $0.2 \%$ & $\begin{array}{c}26.9 \% \\
(2)\end{array}$ & $7.2 \%$ & $10.7 \%$ \\
\hline Drugs \& Biotech. & 64,014 & $\begin{array}{c}49.7 \% \\
(1)\end{array}$ & $\begin{array}{c}17.0 \% \\
\text { (3) }\end{array}$ & $0.0 \%$ & $0.9 \%$ & $\begin{array}{c}32.0 \% \\
(2)\end{array}$ & $0.3 \%$ \\
\hline Metals & 2,688 & $9.4 \%$ & $\begin{array}{c}20.9 \% \\
\text { (3) }\end{array}$ & $0.7 \%$ & $\begin{array}{c}42.7 \% \\
\text { (1) }\end{array}$ & $5.1 \%$ & $\begin{array}{c}21.2 \% \\
(2)\end{array}$ \\
\hline $\begin{array}{l}\text { Machinery, Except } \\
\text { Computers }\end{array}$ & 1,658 & $\begin{array}{c}6.8 \% \\
(3)\end{array}$ & $5.1 \%$ & $2.1 \%$ & $\begin{array}{c}61.6 \% \\
(1)\end{array}$ & $1.5 \%$ & $\begin{array}{c}22.9 \% \\
(2)\end{array}$ \\
\hline Computers & 9,210 & $2.8 \%$ & $\begin{array}{c}15.3 \% \\
\text { (3) }\end{array}$ & $13.6 \%$ & $\begin{array}{c}26.5 \% \\
\text { (2) }\end{array}$ & $1.3 \%$ & $\begin{array}{l}40.5 \% \\
\text { (1) }\end{array}$ \\
\hline Electrical Equipment & 22,896 & $2.1 \%$ & $8.2 \%$ & $\begin{array}{c}9.1 \% \\
(3)\end{array}$ & $\begin{array}{c}50.3 \% \\
(1)\end{array}$ & $2.4 \%$ & $\begin{array}{c}27.9 \% \\
(2)\end{array}$ \\
\hline $\begin{array}{l}\text { Transportation } \\
\text { Equipment }\end{array}$ & 21,120 & $5.5 \%$ & $\begin{array}{c}12.5 \% \\
\text { (3) }\end{array}$ & $3.9 \%$ & $\begin{array}{c}49.3 \% \\
(1)\end{array}$ & $1.6 \%$ & $\begin{array}{c}27.3 \% \\
(2)\end{array}$ \\
\hline Instruments & 10,719 & $12.0 \%$ & $18.6 \%$ & $2.6 \%$ & $\begin{array}{l}24.1 \% \\
(2)\end{array}$ & $\begin{array}{l}15.7 \% \\
(3)\end{array}$ & $\begin{array}{c}27.0 \% \\
\text { (1) }\end{array}$ \\
\hline $\begin{array}{l}\text { Miscellaneous Agric. } \\
\text { \& Manuf. }\end{array}$ & 3,074 & $\begin{array}{c}19.2 \% \\
(2)\end{array}$ & $\begin{array}{l}32.4 \% \\
\text { (1) }\end{array}$ & $0.8 \%$ & $\begin{array}{c}19.8 \% \\
\text { (3) }\end{array}$ & $13.9 \%$ & $13.9 \%$ \\
\hline $\begin{array}{l}\text { Communications } \\
\text { Services }\end{array}$ & 26,292 & $3.2 \%$ & $\begin{array}{c}12.1 \% \\
\text { (3) }\end{array}$ & $10.8 \%$ & $\begin{array}{l}22.2 \% \\
(2)\end{array}$ & $0.3 \%$ & $\begin{array}{l}51.4 \% \\
\text { (1) }\end{array}$ \\
\hline $\begin{array}{l}\text { Software \& Business } \\
\text { Services }\end{array}$ & 25,272 & $3.0 \%$ & $15.1 \%$ & $\begin{array}{l}17.7 \% \\
(2)\end{array}$ & $\begin{array}{l}17.1 \% \\
\text { (3) }\end{array}$ & $0.8 \%$ & $\begin{array}{l}46.3 \% \\
\text { (1) }\end{array}$ \\
\hline Industrial Sector & 217,623 & $\begin{array}{c}19.9 \% \\
(3)\end{array}$ & $17.7 \%$ & $5.5 \%$ & $\begin{array}{c}22.4 \% \\
(1.5)\end{array}$ & $12.1 \%$ & $\begin{array}{c}22.4 \% \\
(1.5)\end{array}$ \\
\hline Academic Sector & $1,909,411$ & $\begin{array}{l}33.5 \% \\
(2)\end{array}$ & $10.2 \%$ & $1.5 \%$ & $8.9 \%$ & $\begin{array}{l}34.5 \% \\
(1)\end{array}$ & $\begin{array}{c}11.4 \% \\
\text { (3) }\end{array}$ \\
\hline
\end{tabular}

Source: Institute for Scientific Information (ISI) and authors' calculations. Period is 1981-1999. The top three fields in an industry or sector are shown in bold with ranks shown in parentheses. 
Table II

Influence of Field and Industry on Mean Citation Rates

And Aggregate R\&D Spillovers

\begin{tabular}{|c|c|c|c|}
\hline & Within Field & Between Field & Total \\
\hline \multicolumn{4}{|l|}{$\begin{array}{l}\text { Firms Citing Universities } \\
\text { Total }\end{array}$} \\
\hline Mean Citation Rate & 0.011 & 0.008 & 0.010 \\
\hline Aggregate R\&D Spillover & $226,855.3$ & $88,872.2$ & $315,727.5$ \\
\hline \multicolumn{4}{|l|}{$\begin{array}{l}\text { Firms Citing Other Firms } \\
\text { Within Industry }\end{array}$} \\
\hline Mean Citation Rate & 0.018 & 0.015 & 0.017 \\
\hline Aggregate R\&D Spillover & $36,541.9$ & $20,931.2$ & $57,473.1$ \\
\hline \multicolumn{4}{|l|}{ Between Industry } \\
\hline Mean Citation Rate & 0.017 & 0.013 & 0.015 \\
\hline Aggregate R\&D Spillover & $59,581.2$ & $44,114.1$ & $103,695.3$ \\
\hline \multicolumn{4}{|l|}{ Total } \\
\hline Mean Citation Rate & 0.017 & 0.013 & 0.016 \\
\hline Aggregate R\&D Spillover & $96,123.1$ & $65,045.3$ & $161,168.4$ \\
\hline
\end{tabular}


Table III

Top Four R\&D Spillovers, by Citing Industry and Citing and Cited Science, Firms Citing Universities

\begin{tabular}{|c|c|c|c|}
\hline Citing Industry & Citing Field & Cited Field & $\begin{array}{c}\text { Aggregate R\&D } \\
\text { Spillover }^{\text {a }}\end{array}$ \\
\hline \multirow[t]{4}{*}{ Petrochemicals } & Biology & Biology & $8,507.8$ \\
\hline & Chemistry & Chemistry & $6,426.1$ \\
\hline & Engineering & Engineering & $3,916.2$ \\
\hline & Medicine & Medicine & $3,035.4$ \\
\hline \multirow[t]{4}{*}{ Drugs \& Biotech. } & Biology & Biology & $72,013.6$ \\
\hline & Medicine & Medicine & $45,169.1$ \\
\hline & Biology & Medicine & $24,016.5$ \\
\hline & Medicine & Biology & $17,528.2$ \\
\hline \multirow[t]{4}{*}{ Metals } & Engineering & Engineering & $1,095.1$ \\
\hline & Biology & Biology & 239.5 \\
\hline & Chemistry & Chemistry & 225.7 \\
\hline & Physics & Physics & 220.7 \\
\hline \multirow[t]{4}{*}{ Machinery except Computers } & Engineering & Engineering & 822.3 \\
\hline & Physics & Physics & 159.0 \\
\hline & Physics & Engineering & 121.3 \\
\hline & Medicine & Medicine & 40.6 \\
\hline \multirow[t]{4}{*}{ Computers } & Engineering & Engineering & $2,033.0$ \\
\hline & Physics & Physics & $1,853.4$ \\
\hline & Comp. Science & Comp. Science & $1,492.1$ \\
\hline & Chemistry & Chemistry & 547.7 \\
\hline \multirow[t]{4}{*}{ Electrical Equipment } & Engineering & Engineering & $8,420.7$ \\
\hline & Physics & Physics & $3,798.0$ \\
\hline & Comp. Science & Comp. Science & $3,249.3$ \\
\hline & Physics & Engineering & $1,972.9$ \\
\hline \multirow[t]{4}{*}{ Transportation Equipment } & Engineering & Engineering & 7,807.1 \\
\hline & Physics & Physics & $2,224.8$ \\
\hline & Physics & Engineering & $1,087.2$ \\
\hline & Chemistry & Chemistry & 971.7 \\
\hline \multirow[t]{4}{*}{ Instruments } & Medicine & Medicine & $3,508.5$ \\
\hline & Biology & Biology & $2,190.7$ \\
\hline & Engineering & Engineering & $1,500.5$ \\
\hline & Chemistry & Chemistry & 979.8 \\
\hline
\end{tabular}


Table III

Top Four R\&D Spillovers, by Citing Industry and Citing and Cited Science, Firms Citing Universities

\begin{tabular}{llll}
\hline \multicolumn{1}{c}{ Citing Industry } & \multicolumn{1}{c}{ Citing Field } & \multicolumn{1}{c}{ Cited Field } & $\begin{array}{c}\text { Aggregate R\&D } \\
\text { Spillover }\end{array}$ \\
\hline \hline \multirow{3}{*}{ Communications Services } & Physics & Physics & \\
& $\begin{array}{l}\text { Engineering } \\
\text { Comp. Science }\end{array}$ & $\begin{array}{l}\text { Engineering } \\
\text { Comp. Science }\end{array}$ & $\mathbf{6 , 3 8 3 . 7}$ \\
& Chemistry & Chemistry & $\mathbf{2 , 1 2 7 . 0}$ \\
& & & $1,199.2$ \\
Software \&Business Services & Physics & Physics & \\
& Comp. Science & Comp. Science & $\mathbf{6 , 2 8 0 . 5}$ \\
& Engineering & Engineering & $3,738.5$ \\
& Chemistry & Chemistry & $1,831.5$ \\
& & & $\mathbf{7 5 6 . 3}$ \\
Misc. Agric. \& Manufacturing & Biology & Biology & $\mathbf{6 1 2 . 9}$ \\
& Medicine & Medicine & 458.8 \\
& Chemistry & Chemistry & 388.6 \\
& Engineering & Engineering & \\
\hline
\end{tabular}

Notes: Table reports the top four aggregate R\&D spillovers by citing industry and citing and cited field. The top two aggregate R\&D spillovers into each industry are shown in bold. Aggregate R\&D spillover is the sum over citing and cited cells of the citation rate times the cited R\&D stock (in millions of 1992 dollars). Here the citation rate $c_{i j} / n_{j}$ is the number of citations from citing industry and industrial science field $i$ to the cited academic science field $j$ divided by the number of potentially cited papers in $j$. 
Table IV

Top Six R\&D Spillovers, by Citing and Cited Industry and Field, Firms Citing Other Firms

\begin{tabular}{|c|c|c|c|c|}
\hline $\begin{array}{l}\text { Citing } \\
\text { Industry }\end{array}$ & $\begin{array}{c}\text { Cited } \\
\text { Industry }\end{array}$ & $\begin{array}{l}\text { Citing } \\
\text { Field }\end{array}$ & $\begin{array}{l}\text { Cited } \\
\text { Field }\end{array}$ & $\begin{array}{l}\text { Aggregate } \\
\text { R\&D } \\
\text { Spillover }\end{array}$ \\
\hline \multirow[t]{6}{*}{ Petrochemicals } & Petrochemicals & Chemistry & Chemistry & $2,742.3$ \\
\hline & Software \& Bus. Services & Chemistry & Chemistry & $1,312.6$ \\
\hline & Drugs \& Biotech. & Biology & Biology & $1,065.7$ \\
\hline & Petrochemicals & Biology & Biology & $1,031.5$ \\
\hline & Software \& Bus. Services & Physics & Physics & 964.5 \\
\hline & Instruments & Chemistry & Chemistry & 884.3 \\
\hline \multirow[t]{6}{*}{ Drugs \& Biotech. } & Drugs \& Biotech. & Biology & Biology & $17,966.7$ \\
\hline & Drugs \& Biotech. & Biology & Medicine & $6,271.1$ \\
\hline & Drugs \& Biotech. & Medicine & Medicine & $4,704.0$ \\
\hline & Drugs \& Biotech. & Medicine & Biology & $4,670.0$ \\
\hline & Drugs \& Biotech. & Chemistry & Chemistry & $4,647.8$ \\
\hline & Drugs \& Biotech. & Chemistry & Biology & $2,737.7$ \\
\hline \multirow[t]{6}{*}{ Metals } & Communications Services & Physics & Physics & 197.6 \\
\hline & Petrochemicals & Chemistry & Chemistry & 173.1 \\
\hline & Software \& Bus. Services & Physics & Physics & 131.5 \\
\hline & Drugs \& Biotech. & Chemistry & Chemistry & 126.7 \\
\hline & Software \& Bus. Services & Chemistry & Chemistry & 91.5 \\
\hline & Software \& Bus. Services & Chemistry & Physics & 65.3 \\
\hline \multirow{6}{*}{$\begin{array}{l}\text { Machinery except } \\
\text { Computers }\end{array}$} & Software \& Bus. Services & Physics & Physics & 308.3 \\
\hline & Software \& Bus. Services & Engineering & Engineering & 204.9 \\
\hline & Communications Services & Physics & Physics & 139.3 \\
\hline & Electrical Equipment & Engineering & Engineering & 74.8 \\
\hline & Electrical Equipment & Physics & Physics & 67.7 \\
\hline & Software \& Bus. Services & Engineering & Physics & 65.4 \\
\hline \multirow[t]{6}{*}{ Computers } & Software \& Bus. Services & Physics & Physics & $1,732.2$ \\
\hline & Communications Services & Physics & Physics & 778.2 \\
\hline & Software \& Bus. Services & Comp. Science & Comp. Science & 500.7 \\
\hline & Software \& Bus. Services & Physics & Chemistry & 496.2 \\
\hline & Instruments & Physics & Physics & 372.4 \\
\hline & Software \& Bus. Services & Chemistry & Chemistry & 339.9 \\
\hline \multirow[t]{2}{*}{ Electrical Equipment } & Software \& Bus. Services & Physics & Physics & $2,743.2$ \\
\hline & Communications Services & Physics & Physics & $2,709.9$ \\
\hline
\end{tabular}


Table IV

Top Six R\&D Spillovers, by Citing and Cited Industry and Field, Firms Citing Other Firms

\begin{tabular}{|c|c|c|c|c|}
\hline $\begin{array}{l}\text { Citing } \\
\text { Industry }\end{array}$ & $\begin{array}{c}\text { Cited } \\
\text { Industry }\end{array}$ & $\begin{array}{l}\text { Citing } \\
\text { Field }\end{array}$ & $\begin{array}{l}\text { Cited } \\
\text { Field }\end{array}$ & $\begin{array}{c}\text { Aggregate } \\
\text { R\&D } \\
\text { Spillover }\end{array}$ \\
\hline \multirow[t]{4}{*}{ Electrical Equipment } & Communications Services & Physics & Engineering & $1,528.7$ \\
\hline & Communications Services & Physics & Chemistry & $1,262.1$ \\
\hline & Software \& Bus. Services & Comp. Science & Comp. Science & $1,200.1$ \\
\hline & Communications Services & Physics & Biology & 884.0 \\
\hline \multirow{6}{*}{$\begin{array}{l}\text { Transportation } \\
\text { Equipment }\end{array}$} & Software \& Bus. Services & Physics & Physics & $1,205.4$ \\
\hline & Communications Services & Physics & Physics & 964.7 \\
\hline & $\begin{array}{l}\text { Transportation } \\
\text { Equipment }\end{array}$ & Engineering & Engineering & 468.3 \\
\hline & Electrical Equipment & Engineering & Engineering & 369.2 \\
\hline & Software \& Bus. Services & Chemistry & Chemistry & 282.6 \\
\hline & Electrical Equipment & Physics & Physics & 274.0 \\
\hline \multirow[t]{6}{*}{ Instruments } & Software \& Bus. Services & Physics & Physics & 805.1 \\
\hline & Communications Services & Physics & Physics & 400.2 \\
\hline & Drugs \& Biotech. & Biology & Biology & 358.1 \\
\hline & Petrochemicals & Chemistry & Chemistry & 346.2 \\
\hline & Software \& Bus. Services & Chemistry & Chemistry & 290.9 \\
\hline & Software \& Bus. Services & Chemistry & Physics & 257.6 \\
\hline \multirow{6}{*}{$\begin{array}{l}\text { Communications } \\
\text { Services }\end{array}$} & Software \& Bus. Services & Physics & Physics & $2,099.5$ \\
\hline & Software \& Bus. Services & Physics & Chemistry & $1,641.4$ \\
\hline & Software \& Bus. Services & Physics & Engineering & $1,199.4$ \\
\hline & Software \& Bus. Services & Physics & Biology & 756.9 \\
\hline & Software \& Bus. Services & Physics & Comp. Science & 638.1 \\
\hline & Software \& Bus. Services & Chemistry & Physics & 497.2 \\
\hline \multirow[t]{6}{*}{ Software \& Bus. Services } & Communications Services & Physics & Physics & $1,402.1$ \\
\hline & Communications Services & Physics & Chemistry & $1,073.2$ \\
\hline & Communications Services & Physics & Biology & 842.1 \\
\hline & Communications Services & Physics & Engineering & 788.9 \\
\hline & Software \& Bus. Services & Comp. Science & Comp. Science & 642.2 \\
\hline & Petrochemicals & Chemistry & Chemistry & 473.0 \\
\hline \multirow[t]{4}{*}{ Misc. Agric. \& Manuf. } & Petrochemicals & Chemistry & Chemistry & 200.1 \\
\hline & Software \& Bus. Services & Physics & Physics & 162.5 \\
\hline & Software \& Bus. Services & Chemistry & Chemistry & 117.4 \\
\hline & Instruments & Chemistry & Chemistry & 90.0 \\
\hline
\end{tabular}


Table IV

Top Six R\&D Spillovers, by Citing and Cited Industry and Field, Firms Citing Other Firms

\begin{tabular}{|c|c|c|c|c|}
\hline $\begin{array}{l}\text { Citing } \\
\text { Industry }\end{array}$ & $\begin{array}{c}\text { Cited } \\
\text { Industry }\end{array}$ & $\begin{array}{l}\text { Citing } \\
\text { Field }\end{array}$ & $\begin{array}{l}\text { Cited } \\
\text { Field }\end{array}$ & $\begin{array}{c}\text { Aggregate } \\
\text { R\&D } \\
\text { Spillover a }\end{array}$ \\
\hline Misc. Agric. \& Manuf. & $\begin{array}{l}\text { Drugs \& Biotech. } \\
\text { Communications Services }\end{array}$ & $\begin{array}{l}\text { Biology } \\
\text { Physics }\end{array}$ & $\begin{array}{l}\text { Biology } \\
\text { Physics }\end{array}$ & $\begin{array}{l}84.1 \\
78.2\end{array}$ \\
\hline
\end{tabular}

Notes: Table reports the top six aggregate R\&D spillovers by citing and cited industry and field. The top three aggregate R\&D spillovers into each industry are shown in bold. ${ }^{a}$ Aggregate R\&D spillover is the sum over citing and cited cells of the citation rate times the cited R\&D stock (in millions of 1992 dollars). Here the citation rate $c_{i j k} / n_{k}$ is the number of citations from citing industry $i$ and industrial science field $j$ to industry $k$, divided by the number of potentially cited papers in $k$. 
Table V

Herfindahl Indexes of the Concentration of R\&D Spillovers, by Citing Industry

\begin{tabular}{|c|c|c|c|}
\hline \multirow[t]{2}{*}{ Citing Industry } & \multirow{2}{*}{$\begin{array}{l}\text { Herfindahl Index } \\
\text { for Academic } \\
\text { Spillover: } \\
\text { By Cited Field }\end{array}$} & \multicolumn{2}{|c|}{$\begin{array}{l}\text { Herfindahl Index for } \\
\text { Industrial Spillover: }\end{array}$} \\
\hline & & $\begin{array}{l}\text { By Cited } \\
\text { Field }\end{array}$ & $\begin{array}{l}\text { By Cited } \\
\text { Industry }\end{array}$ \\
\hline Petrochemicals & 0.23 & 0.28 & 0.20 \\
\hline Drugs \& Biotech. & $0.47^{*}$ & $0.41 *$ & $0.70 *$ \\
\hline Metals & 0.33 & 0.26 & 0.16 \\
\hline Machinery, Except Computers & $0.51 *$ & $0.39 *$ & 0.33 \\
\hline Computers & 0.25 & 0.31 & 0.31 \\
\hline Electrical Equipment & 0.31 & 0.27 & 0.30 \\
\hline Transportation Equipment & 0.39 & 0.32 & 0.19 \\
\hline Instruments & 0.25 & 0.26 & 0.17 \\
\hline Miscellaneous Agric. \& Manuf. & 0.23 & 0.27 & 0.18 \\
\hline Communications Services & 0.28 & 0.25 & $0.44^{*}$ \\
\hline Software \& Business Services & 0.25 & 0.27 & 0.28 \\
\hline Average & 0.32 & 0.30 & 0.30 \\
\hline Lower Bound & 0.17 & 0.17 & 0.09 \\
\hline
\end{tabular}

Notes: See the text for definitions of the Herfindahl indexes. *Top two most concentrated industries. 
Table VI

Production Functions for Scientific Papers, by Industry and Field

\begin{tabular}{|c|c|c|c|c|c|c|c|c|c|}
\hline \multirow[t]{2}{*}{ Variable or Statistic } & \multicolumn{7}{|c|}{ Dependent Variable: Log (Papers) } & \multicolumn{2}{|c|}{$\begin{array}{c}\text { Dependent Variable: } \\
\text { Log (Citation-Weighted } \\
\text { Papers) }\end{array}$} \\
\hline & VI.1 & VI.2 & VI.3 & VI.4 & VI.5 & VI.6 & VI.7 & VI.8 & VI.9 \\
\hline Estimation Method & OLS & OLS & OLS & OLS & OLS & OLS & OLS & OLS & OLS \\
\hline Industry Dummies & No & No & No & Yes & Yes & Yes & Yes & No & Yes \\
\hline Field Dummies & No & No & No & Yes & Yes & Yes & Yes & No & Yes \\
\hline Year Dummies & No & No & No & Yes & Yes & Yes & Yes & No & Yes \\
\hline Sample & Full & Full & Full & Full & Full & Drop Drugs & Drop Metals, & Drop Years & Drop Years \\
\hline & Sample & Sample & Sample & Sample & Sample & \& Biotech. & Mach., Misc. & 1996-1999 & 1996-1999 \\
\hline Log (Industry Basic Research & $0.850 * *$ & $0.137 * *$ & $0.098 * *$ & $0.227^{*} *$ & $0.180^{* *}$ & $0.195 * *$ & $0.097 *$ & $0.149 * *$ & $-0.169 *$ \\
\hline Stock) $\left(\beta_{R}\right)$ & $(0.040)$ & $(0.033)$ & $(0.022)$ & $(0.049)$ & $(0.038)$ & $(0.042)$ & $(0.042)$ & $(0.044)$ & $(0.082)$ \\
\hline Log (Academic Research & & $0.530 * *$ & $0.496 * *$ & $0.574^{* *}$ & $0.565 * *$ & $0.542 * *$ & $0.631^{* *}$ & $0.486 * *$ & $0.655 * *$ \\
\hline Spillover $)\left(\beta_{A}\right)$ & & $(0.055)$ & $(0.031)$ & $(0.071)$ & $(0.043)$ & $(0.049)$ & $(0.045)$ & $(0.046)$ & $(0.062)$ \\
\hline Zero Spillover Dummy × & & & $-0.477 * *$ & & $-0.571 * *$ & $-0.579 * *$ & $-0.664 * *$ & $-0.560 * *$ & $-0.776 * *$ \\
\hline Log (Academic Res. Spillover) & & & $(0.069)$ & & $(0.073)$ & $(0.079)$ & $(0.094)$ & $(0.161)$ & $(0.135)$ \\
\hline Log (Industrial Research & & $0.155^{* *}$ & $0.319 * *$ & $0.096 * *$ & $0.244 * *$ & $0.228 * *$ & $0.227 * *$ & $0.485 * *$ & $0.355 * *$ \\
\hline Spillover) $\left(\beta_{I}\right)$ & & $(0.022)$ & & $(0.031)$ & & & & & \\
\hline Zero Spillover Dummy × & & & $-0.322 * *$ & & $-0.274^{* *}$ & $-0.245 * *$ & $-0.253 * *$ & $-0.455^{* *}$ & $-0.308 * *$ \\
\hline Log (Industrial Res. Spillover) & & & $(0.028)$ & & $(0.035)$ & $(0.040)$ & $(0.042)$ & $(0.046)$ & $(0.058)$ \\
\hline Number of Observations & 747 & 747 & 747 & 747 & 747 & 663 & 559 & 478 & 478 \\
\hline R-square & 0.350 & 0.866 & 0.908 & 0.914 & 0.946 & 0.942 & 0.963 & 0.864 & 0.923 \\
\hline Root Mean Square Error & 1.405 & 0.639 & 0.530 & 0.520 & 0.398 & 0.379 & 0.330 & 0.760 & 0.584 \\
\hline
\end{tabular}

Notes: Full sample is an imbalanced panel that includes 11 industry groups, up to six science fields, and up to 12 years from 19881999. Robust standard errors appear in parentheses. ** Coefficient is significantly different from zero at the one percent level. *

Coefficient is significantly different from zero at the five percent level. 
Table VII

Production Functions for Scientific Papers, Decomposition of Spillovers Within and Between Fields and Industries

\begin{tabular}{|c|c|c|c|}
\hline Variable or Statistic & VII.1 & VII.2 & VII.3 \\
\hline Estimation Method & OLS & OLS & OLS \\
\hline Industry Dummies & Yes & Yes & Yes \\
\hline Field Dummies & Yes & Yes & Yes \\
\hline Year Dummies & Yes & Yes & Yes \\
\hline Log (Industry Basic Research Stock) & $\begin{array}{c}0.196 * * \\
(0.041)\end{array}$ & $\begin{array}{c}0.199 * * \\
(0.041)\end{array}$ & $\begin{array}{c}0.207 * * \\
(0.040)\end{array}$ \\
\hline $\log ($ WF Academic Research Spillover $)\left(\gamma_{A, W F}\right)$ & $\begin{array}{c}0.378 * * \\
(0.051)\end{array}$ & $\begin{array}{c}0.380 * * \\
(0.049)\end{array}$ & $\begin{array}{c}0.367 * * \\
(0.051)\end{array}$ \\
\hline Zero WF Academic Spillover Dummy $\times$ & $-0.333 * *$ & $-0.333 * *$ & $-0.320 * *$ \\
\hline Log (WF Academic Research Spillover) & $(0.069)$ & $(0.068)$ & $(0.069)$ \\
\hline Log (BF Academic Research Spillover) $\left(\gamma_{A, B F}\right)$ & $\begin{array}{c}0.183 * * \\
(0.035)\end{array}$ & $\begin{array}{c}0.191^{* *} \\
(0.035)\end{array}$ & $\begin{array}{c}0.185^{* *} \\
(0.034)\end{array}$ \\
\hline Zero BF Academic Spillover Dummy $\times$ & $-0.148 * *$ & $-0.155^{* *}$ & $-0.150 * *$ \\
\hline Log (BF Academic Research Spillover) & $(0.041)$ & $(0.041)$ & $(0.040)$ \\
\hline Log (WF Industrial Research Spillover) $\left(\gamma_{I, W F}\right)$ & $\begin{array}{c}0.146^{* *} \\
(0.028)\end{array}$ & & \\
\hline Zero WF Industrial Spillover Dummy $\times$ & $-0.147 * *$ & & \\
\hline Log (WF Industrial Research Spillover) & $(0.033)$ & & \\
\hline Log (BF Industrial Research Spillover) $\left(\gamma_{I, B F}\right)$ & $\begin{array}{c}0.108 * \\
(0.025)\end{array}$ & & \\
\hline Zero BF Industrial Spillover Dummy $\times$ & $-0.116^{*}$ & & \\
\hline Log (BF Industrial Research Spillover) & $(0.029)$ & & \\
\hline Log (WI Industrial Research Spillover) $\left(\gamma_{I, W I}\right)$ & & $\begin{array}{c}0.117^{* *} \\
(0.017)\end{array}$ & \\
\hline Zero WI Industrial Spillover Dummy $\times$ & & $-0.114 * *$ & \\
\hline Log (WI Industrial Research Spillover) & & $(0.020)$ & \\
\hline Log (BI Industrial Research Spillover) $\left(\gamma_{I, B I}\right)$ & & $\begin{array}{c}0.150 * * \\
(0.030)\end{array}$ & \\
\hline Zero BI Industrial Spillover Dummy $\times$ & & $-0.157 * *$ & \\
\hline Log (BI Industrial Research Spillover) & & $(0.039)$ & \\
\hline Log (WF, WI Industrial Res. Spillover) $\left(\gamma_{I, W F W I}\right)$ & & & $\begin{array}{c}0.100 * * \\
(0.016)\end{array}$ \\
\hline Zero WF, WI Industrial Spillover Dummy $\times$ & & & $-0.087 * *$ \\
\hline Log (WF, WI Industrial Research Spillover) & & & $(0.019)$ \\
\hline Log (WF, BI Industrial Res. Spillover $)\left(\gamma_{I, W F B I}\right)$ & & & $\begin{array}{c}0.087 * * \\
(0.027)\end{array}$ \\
\hline
\end{tabular}




\section{Table VII \\ Production Functions for Scientific Papers, Decomposition of Spillovers Within and Between Fields and Industries}

\begin{tabular}{|c|c|c|c|}
\hline Variable or Statistic & VII.1 & VII.2 & VII.3 \\
\hline $\begin{array}{l}\text { Zero WF, BI Industrial Spillover Dummy × } \\
\text { Log (WF, BI Industrial Research Spillover) } \\
\text { Log (BF, WI Industrial Research Spillover) } \\
\left(\gamma_{I, B F W I}\right)\end{array}$ & & & $\begin{array}{c}-0.077 * \\
(0.032) \\
0.013 \\
(0.017)\end{array}$ \\
\hline $\begin{array}{l}\text { Zero BF, WI Industrial Spillover Dummy } \times \\
\text { Log (BF, WI Industrial Research Spillover }) \\
\text { Log (BF, BI Industrial Research Spillover })\left(\gamma_{I, B F B I}\right)\end{array}$ & & & $\begin{array}{c}-0.014 \\
(0.018) \\
0.087^{* *} \\
(0.023)\end{array}$ \\
\hline $\begin{array}{l}\text { Zero BF, BI Industrial Spillover Dummy × } \\
\text { Log (BF, BI Industrial Research Spillover) }\end{array}$ & & & $\begin{array}{l}-0.085^{*} \\
(0.028)\end{array}$ \\
\hline $\begin{array}{l}\text { R-square } \\
\text { Root Mean Square Error }\end{array}$ & $\begin{array}{l}0.955 \\
0.379\end{array}$ & $\begin{array}{l}0.956 \\
0.374\end{array}$ & $\begin{array}{l}0.957 \\
0.372\end{array}$ \\
\hline
\end{tabular}

Notes: Number of observations is $N=747$. Sample is an imbalanced panel that includes 11 industry groups and up to six science fields and 12 years from 1988-1999. Robust standard errors appear in parentheses. ${ }^{* *}$ Coefficient is significantly different from zero at the one percent level. * Coefficient is significantly different from zero at the five percent level. 


\begin{tabular}{|c|c|c|c|c|c|}
\hline \multirow{2}{*}{ Test of Restriction } & \multicolumn{5}{|c|}{ Wald F-Statistic } \\
\hline & Eq. VI.3 & Eq. VI.5 & Eq. VII.1 & Eq. VII.2 & Eq. VII.3 \\
\hline 1. $\beta_{R}=\beta_{A}$ & $72.1^{* *}$ & $34.7^{* *}$ & & & \\
\hline 2. $\beta_{A}=\beta_{I}$ & $12.9^{* *}$ & $18.6^{* *}$ & & & \\
\hline 3. $\gamma_{A, W F}=\gamma_{A, B F}$ & & & $6.0 * *$ & $5.8^{*}$ & $5.4^{*}$ \\
\hline 4. $\gamma_{A, W F}=\gamma_{I, W F}$ & & & $9.9 * *$ & & \\
\hline 5. $\gamma_{A, B F}=\gamma_{I, B F}$ & & & 3.5 & & \\
\hline 6. $\gamma_{I, W F}=\gamma_{I, B F}$ & & & 1.0 & & \\
\hline 7. $\gamma_{I, W I}=\gamma_{I, B I}$ & & & & 1.3 & \\
\hline 8. $\gamma_{I, W F W I}=\gamma_{I, B F W I}$ & & & & & $11.0^{* *}$ \\
\hline 9. $\gamma_{I, W F B I}=\gamma_{I, B F B I}$ & & & & & 0.0 \\
\hline 10. $\gamma_{I, W F W I}=\gamma_{I, W F B I}$ & & & & & 0.2 \\
\hline 11. $\gamma_{I, B F W I}=\gamma_{I, B F B I}$ & & & & & $6.9^{* *}$ \\
\hline
\end{tabular}

Notes: The null $\mathrm{H}_{0}$ tests for equality of the indicated coefficient restrictions. ${ }^{* *}$ Test statistic is significant at the one percent level. * Test statistic is significant at the two percent level. Significant values of the F-statistic indicate rejection of $\mathrm{H}_{0}$. Insignificant values indicate acceptance of $\mathrm{H}_{0}$. 